\title{
HEART FAILURE IN WOMEN
}

\author{
Kadiyala Meenakshi
}

Heart failure is a growing health problem worldwide, and women account for nearly $50 \%$ of all hospital admissions for the same. At 40 , the prevalence of heart failure is higher in men than in women, but this ratio reverses after 80years. Systemic hypertension and ischemic heart disease are the common culprits in women and reasons for gender differences are multifactorial. The heart failure usually occurs with preserved ejection fraction, symptoms are generally more severe and prognosis seems to be better in women. Management should be similar to men, in spite of the fact that in randomized studies women are poorly represented.

Epidemiology

The incidence of heart failure (HF) in women has dropped by one-third from the 1950s through the 1990s but has remained unchanged in men over the period $[1,2]$ After the age of 40 , the prevalence of heart failure is higher among men at a ratio of 2:1 approximately. This ratio reverses after the age of 80 as women outnumber men at that age (Table 1).

Table 1: Prevalence (\%) of heart failure by gender and age (years) according to Taylor AL

\begin{tabular}{|l|l|l|l|l|}
\hline Age & $\mathbf{2 0 - 3 9}$ & $\mathbf{4 0 - 5 9}$ & $\mathbf{6 0 - 7 9}$ & $\mathbf{8 0 +}$ \\
\hline Men & 0.2 & 1.5 & 7.8 & 8.6 \\
\hline Women & 0.4 & 0.7 & 4.5 & 11.5 \\
\hline
\end{tabular}

Genetic and physiological basis for gender difference Mechanisms that could cause these sex differences could be: a) Inherent biological gender differences in the manifestation of the disease, treatment response, and the natural history of the disease, b) Variations in comorbidity and c) Differences in care [3].

Mean systolic and diastolic pressure is higher in young men than women in all ethnic groups. Declining oestrogen levels reverses this ratio in postmenopausal

Article received on 17 APR 2017, published on 30 APR 2017.

Kadiyala Meenakshi ${ }^{1}$

${ }^{1}$ Professor Department of Cardiology, Saveetha medical College, Chennai, India Corresponding author: Kadiyala Meenakshi

Email: drmeenaram@gmail.com women. Further, hypertension (HT) of pregnancy increase the long term risk for HF $[4,5,6]$.

\section{Risk factors and aetiology}

Although any factor listed, can set the stage for HF, some are more likely in women.

Framingham study reported that $60 \%$ of women and $40 \%$ of men with heart failure gave a history of hypertension. Levy et al [18] observed that risk for HF in hypertensive when compared to normotensive, was twice as high in men and three times higher in women [10,12].

Framingham Heart Study also reported that diabetic women, even at ages 35 to 64 , were twice as likely to develop HF as diabetic men of the same age.

In acute coronary syndromes, women are more prone to develop acute heart failure than men. The Euro Heart Survey of Stable Angina observed that inadequate and casual management of IHD in women in the past may be the cause for a higher incidence and early prevalence of HF in elderly women after MI [18].

Valvular heart disease particularly obstructive pathology (aortic stenosis/mitral stenosis) is another important cause of HF in women, than in men. The heart fails particularly during pregnancy and in the elderly.

Pericardial constriction following radiotherapy for breast cancer and Chemotherapy with Anthracyclines (doxorubicin \& Adriamycin) used in breast cancer have an elevated risk for HF.

Although rare, peripartum cardiomyopathy is a unique cause of HF in women. Women over 35yrs, African American, or with pregnancy induced diabetes are at a greater risk.

Alcohol abuse is a cause of HF in both genders, but 10 times more so in women.

Severe lung disease, primary pulmonary hypertension, and recurrent pulmonary thromboembolism are yet another cause in females.

Obese women had a $50 \%$ greater risk of HF than women of normal weight. Kenchaiah et al [11] reported that the risk increased by $5 \%$ in men and $7 \%$ in women for each unit of BMI increase.

Sleep apnea, is common in persons with HF, although its precise role in the development or course of the disease is unknown. 


\section{Pathophysiology}

The most important feature of HF in women is concentric hypertrophy and preserved ejection fraction (HFpEF), whereas HF in men is associated with reduced (HFrEF) ejection fraction. The renin-angiotensin system is less activated and fibrosis is minimal at a myocardial level, However, there is a general stiffening of the heart with an increase in the end diastolic pressure. The reason for the preferential concentric hypertrophy and HFpEF is not clear. One postulation is that in women, myocytes diameter is less when compared to men, and it may therefore be possible to increase a number of contractile proteins without stretching the sarcomere [7].

\section{Clinical presentation}

Depression is a common symptom in women with HF. Women scored significantly higher than men in the Beck depression inventory. Depression worsens prognosis 45. Fatigue is common and occurs early in women and even performing simple tasks may be exhausting.

Ankle edema, shortness of breath, orthopnea, persistent cough, rapid heart rate and loss of appetite also occur.

\section{Treatment}

Clinicians cannot afford to be complacent in the management of women with HF. Treatment is not gender-specific and current guidelines should be followed although female representation in clinical trials is only $30 \%$.Studies have revealed that women receive less optimal care than men with lower use of combined therapy and lower compliance. Women also do not receive detailed instructions at discharge regarding diet and fluid intake, weight control, and medications.

Cytochrome P450 isoenzyme activity differs in men and women (Table 2).
Table 2: Gender Differences in Cytochrome P450 Isoenzyme activity. According to Regitz-Zagrosek $\mathrm{V}$ et al

\begin{tabular}{|l|l|l|}
\hline Iseonzyme & Gender Difference & $\begin{array}{l}\text { Cardiovascular Relevant } \\
\text { Substrate }\end{array}$ \\
\hline CYPIA2 & $\begin{array}{l}\text { Lower in women, } \\
\text { hormone-sensitive }\end{array}$ & Caffeine paracetamol \\
\hline CYP2C9 & $\begin{array}{l}\text { No Gender } \\
\text { difference }\end{array}$ & Warfarin \\
\hline CYP2C19 & Controversial & Omeprazol Diazepam \\
\hline CYP2D6 & $\begin{array}{l}\text { Higher activity in } \\
\text { males }\end{array}$ & Propanolol Metoprolol \\
\hline CYP2E1 & $\begin{array}{l}\text { Higher activity in } \\
\text { males }\end{array}$ & Halotan Isofluoran \\
\hline CYP3A4 & $\begin{array}{l}\text { Higher activity in } \\
\text { females }\end{array}$ & $\begin{array}{l}\text { Tacrolimus Ditiazem } \\
\text { Nifedipin Triazelam } \\
\text { Cyclosporin Verpamil }\end{array}$ \\
\hline
\end{tabular}

The consequences are particularly important for betablockers and calcium blocking agents, whose action is respectively increased and decreased in females respectively [11].

\section{REFERENCES:}

1. Levy D, Kenchaiah S, Larson MG, et al. Long-term trends in the incidence of and survival with heart failure. N Engl J Med 2002; 347: 1397-402.

2. Kannel WB. Epidemiological aspects of heart failure. Cardiol Clin 1989; 7:1-9.

3. Charchar F J, Tomaszewski M, Lacka B, et al. Association of the human $\mathrm{Y}$ chromosome with cholesterol levels in the general population. Arterioscler Thromb Vasc Biol 2004; 24, 308-12. 9. Charchar FJ, Bloomer LD, Barnes TA,

4. Tank J, Diedrich A, Szczech E, Luft FC, Jordan J. Barorefl ex regulation of heart rate and sympathetic vasomotor tone in women and men. Hypertension 2005; 45: 1159-64.

5. Barnes J, Matzek LJ, Charkoudian N, Joyner MJ, Curry TB, Hart EC. Association of cardiac barorefl ex sensitivity with blood pressure transients: infl uence of sex and menopausal status. Front Physiol 2012; 3: 187. 21. 
6. Shoemaker JK, Hogeman CS, Khan M, Kimmerly DS, Sinoway LI. Gender affects sympathetic and hemodynamic response to postural stress. Am J Physiol Heart Circ Physiol 2001; 281: H2028-35.

7. Renato Razzolini1, Carlo Dal Lin1 Gender differences in heart failure Ital J Gender-Specifi c Med 2015; 1: 15-20

8. María G Crespo Leiro a, María J Paniagua Martín a Heart Failure. Are Women Different? Servicio de Cardiología, Área del Corazón, Complejo Hospitalario Universitario Juan Canalejo, A Coruña, Spain

9. Taylor AL. Heart failure in women. Curr Heart Fail Rep 2015; 12: 187-95.

10. Iseki K, Kimura Y, Wakugami K, et al. Comparison of the effect of blood pressure on the development of stroke, acute myoca0dial infarction, and end-stage renal disease. Hypertens Res 2000; 23, 143-9.

11. Kenchaiah S, Evans JC, Levy D, et al. Obesity and the risk of heart failure. N Engl J Med 2002; 347(5): 305-13.

12. Levy D, Larson MG, Vasan RS, KannelWB, Ho KK. The progression from hypertension to congestive heart failure. JAMA 1996; 275(20): 1557-62.

13. Nieminen MS, Harjola VP, Hochadel $M$, et al. Gender related differences in patients presenting with acute heart failure. Results from EuroHeart Failure Survey II. Eur J Heart Fail 2008; 10(2): 140-8.

14. Herz ND, Engeda J, Zusterzeel $R$, et al. Sex differences in device therapy for heart failure: utilization, outcomes, and adverse events. J Womens Health (Larchmt). 2015; 24(4): 261-71.

15. Ho KK, Anderson KM, Kannel WB, Grossman W, Levy D. Survival after the onset of congestive heart failure in Framingham Heart Study subjects. Circulation 1993; 88: 107-15.

16. Lund LH, Mancini D. Heart failure in women. Med Clin North Am 2004; 88: 1321-1345, xii.

17. Ghali JK, Krause-Steinrauf HJ, Adams KF, et al. Gender difference in advanced heart failure: insights from the BEST study. J Am Coll Cardiol 2003; 42: 212834.

18. Scantlebury DC, Borlaug BA. Why are women more likely than men to develop heart failutre with preserved ejection fraction? Curr Op Cardiol 2011; 26: 562-8.

19. Azevedo A, Bettencourt P, Frioes F, et al. Depressive symptoms and heart failure stages. Psychosomatics 2008; 49: 42-8.

20. The CONSENSUS Trial Study Group. Effects of enalapril on mortality in severe congestive heart failure. Results of the Cooperative North Scandinavian Enalapril Survival Study (CONSENSUS). N Engl J Med 1987; 316: 142935.

21. Shekelle PG, Rich MW, Morton SC, et al. Efficacy of angiotensin-converting enzyme inhibitors and betablockers in the management of left ventricular systolic dysfunction according to race, gender, and diabetic status: a meta-analysis of major clinical trials. J Am Coll Cardiol 2003; 41: 1529. 